\title{
Epidemiology of Oestrus ovis (Diptera: Oestridae) in sheep in Botucatu, State of Sáo Paulo
}

\author{
Epidemiologia de Oestrus ovis (Diptera: Oestridae) em ovinos em Botucatu, São Paulo \\ Bruna Fernanda da Silva ${ }^{1 *}$; César Cristiano Bassetto ${ }^{1}$; Alessandro Francisco Talamini do Amarante ${ }^{1}$ \\ ${ }^{1}$ Departamento de Parasitologia, Instituto de Biociências, Universidade Estadual Paulista - UNESP, Botucatu, SP, Brasil
}

Received May 10, 2012

Accepted September 17, 2012

\begin{abstract}
The seasonal factors that influence Oestrus ovis infestation in sheep were determined in Botucatu, State of São Paulo, Southwestern Brazil, from April 2008 to March 2011. Two tracer lambs were monthly exposed to natural infestation by O. ovis larvae for 28 consecutive days, by grazing with a sheep flock. Tracer animals were then euthanized and the larvae of $O$. ovis recovered from nasal and sinus cavities. Of the 72 tracer lambs, $50 \%$ were infested with $O$. ovis larvae and the mean intensity of infestation per head infested was 16.8 larvae, with an average of $7.8 \mathrm{~L} 1,5.3 \mathrm{~L} 2$ and $3.7 \mathrm{~L} 3$. O. ovis larvae were present during the four seasons of the year, but the mean larval burden was significantly higher during the spring and summer months, compared to winter $(\mathrm{P}<0.05)$. The highest rate of larvae recovery coincided with mean temperatures between $20{ }^{\circ} \mathrm{C}$ and $25^{\circ} \mathrm{C}$ and air relative humidity around $70 \%$. Results suggest that evolution and development of $O$. ovis practically occurs throughout the entire year, with larval infestation especially frequent during the spring and summer months.
\end{abstract}

Keywords: Oestrus ovis, epidemiology, sheep.

\section{Resumo}

Os fatores sazonais que influenciam a infestação por larvas de Oestrus ovis, foram determinados no período de abril de 2008 a março de 2011, em ovinos criados em Botucatu, São Paulo, região Sudeste do Brasil. Mensalmente, dois cordeiros traçadores permaneceram em pastejo com um rebanho ovino durante 28 dias consecutivos, expostos à infestação natural por larvas de $O$. ovis. Em seguida, os cordeiros foram sacrificados, e as larvas de $O$. ovis recuperadas da cavidade nasal e seios frontais. Dos 72 cordeiros traçadores, 50\% estavam infestados por larvas de $O$. ovis, com intensidade média de infestação de 16,8 larvas/cabeça infestada, com média de 7,8 L1, 5,3 L2 e 3,7 L3. As larvas de $O$. ovis foram recuperadas durante as quatro estaçóes do ano, mas o número médio de larvas foi significativamente superior durante os meses de primavera e verão comparado aos meses de inverno $(\mathrm{P}<0,05)$. A maior taxa de recuperação larval coincidiu com temperaturas médias entre $20^{\circ} \mathrm{C}$ e $25^{\circ} \mathrm{C}$ e umidade relativa do ar por volta de $70 \%$. Os resultados sugerem que a evolução e desenvolvimento de $O$. ovis ocorre praticamente durante o ano inteiro, mas a infestação é mais frequente nos meses de primavera e verão.

Palavras-chave: Oestrus ovis, epidemiologia, ovinos.

\section{Introduction}

Oestrosis is a worldwide myiasis caused by larvae of the fly, Oestrus ovis (Linné 1761, Diptera: Oestridae), which are obligatory parasites of the nasal and sinus cavities of sheep and goats. The female fly is viviparous and deposits larvae in or around the nostrils of its host. These early first instars attach to the mucous membranes in the nasal cavities, change to second instars and move up to the sinuses, where they complete their development into mature third instars, which are expelled for pupation under

*Corresponding author: Bruna Fernanda da Silva

Departamento de Parasitologia, Instituto de Biociências, Universidade Estadual Paulista - UNESP, Distrito de Rubiāo Júnior s/n, CEP 18618-000,

Botucatu, SP, Brasil

e-mail: brusilvabio@gmail.com the soil (ZUMPT, 1965). The length of the parasitic life cycle is quite variable: from a few weeks to several months, depending on the season and climatic conditions (HALL; WALL, 1995). The pupation period may vary, on average, from 28 to 43 days and the average life of flies is around eight days (COBBETT; MITCHELL, 1941). Clinical respiratory signs such as seromucous or purulent nasal discharge, frequent sneezing and dyspnea, may severely impair the health of infested animals (DORCHIES et al., 1998). These pathological changes cause considerable economic losses in small ruminant livestock (ALCAIDE et al., 2003), i.e., reduction in live weight gain (HORAK; SNIJDERS, 1974) and decrease in milk production of almost 9\% (DORCHIES et al., 2003). 
Numerous studies regarding the epidemiology of $O$. ovis have been carried out in many countries, but results are likely to be influenced by varying geographical conditions. In southwestern France, for example, infestation by 0 . ovis was present in $65 \%$ of the animals with mean intensity of 24.8 larvae/infested head, consisting mainly of first larval instar (YILMA; DORCHIES, 1991). In Sicily, Italy, the prevalence of infestation was $55.8 \%$ and all different larval instars were simultaneously recovered in similar proportions (CARACAPPA et al., 2000). In Brazil, there have only been a few studies about this parasite and these are restricted to States in the South of the country, where climatic conditions favorable to $O$. ovis parasitism are observed throughout the year (OLIVEIRA et al., 1999; RIBEIRO et al., 1990; RAMOS et al., 2006), except during periods with temperature of less than $9{ }^{\circ} \mathrm{C}$, when no larvae were recovered from tracer sheep (RAMOS et al., 2006).

Oestrosis is considered a neglected sheep disease in Brazil, despite its increasing occurrence, according to the perception of farmers and veterinary clinicians. Therefore, more research about the epidemiology of the disease is imperative, since such knowledge will allow us to predict environmental factors favoring infestation, as well as enable recommendations regarding the best strategies for oestrosis prophylaxis. This study was conducted to determine the seasonal variation of $O$. ovis infestation in sheep in Southwestern Brazil over a period of three years.

\section{Materials and Methods}

\section{Study location}

The experiment (approved by the Ethics Committee for Animals of the Institution - 86/07 - CEEA) was carried out in a sheep farm of the "Universidade Estadual Paulista" - UNESP, located at $22^{\circ} 82^{\prime}$ latitude South and $48^{\circ} 41^{\prime}$ longitude West, 613 m a.s.l., in Botucatu, State of São Paulo, Brazil. The climate is Cwa type according to Köppen classification and the data referring to averages of temperatures, relative air humidity and rainfall during the study period were obtained by the Department of Environmental Science, Agronomical Science College, UNESP, located $8 \mathrm{~km}$ away from the experimental site (Figure 1a, b).
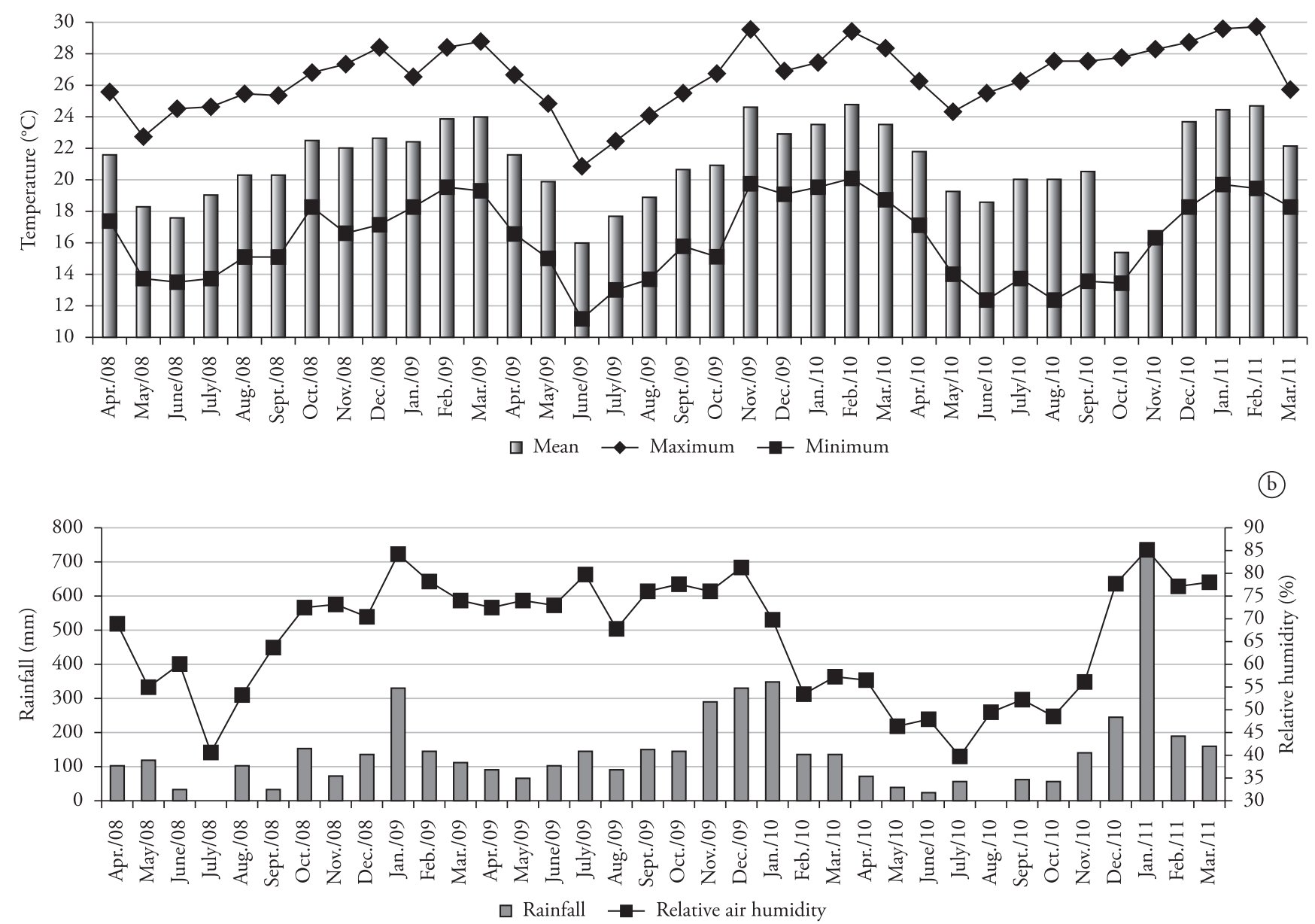

Figure 1. Average maximum, minimum and mean monthly temperatures (a) monthly rainfall and relative air humidity from April 2008 until March 2011 (b) Source: Department of Environmental Sciences, Agronomical Science College, São Paulo State University - UNESP, Botucatu, São Paulo State. 


\section{Management of tracer lambs}

In total, during the three years of observations, 72 Ile de France weathered male lambs were purchased from a farm located in the State of São Paulo. Twelve lambs were purchased every six months, with initial ages between two and five months.

Immediately after arrival at the University facilities, animals were housed, vaccinated against clostridial infections (Sintoxan Polivalente ${ }^{\circledR}$, Merial, Brazil) and orally drenched, once daily, for three consecutive days with levamisole phosphate $(10 \mathrm{mg} / \mathrm{kg}$, Ripercol $^{\circledR}$ L 150 F, Fort Dodge) and albendazole $(10 \mathrm{mg} / \mathrm{kg}$, Valbazen ${ }^{\circledR} 10$ Cobalto, Pfizer). One week later, the same protocol was carried out with triclorfon $\left(100 \mathrm{mg} / \mathrm{kg}\right.$, Neguvon ${ }^{\circledR}$, Bayer S.A.) to remove any existing infestation with $O$. ovis and infection with gastrointestinal nematodes. Tracer lambs that had remained housed for more than one month received an additional treatment with triclorfon $\left(100 \mathrm{mg} / \mathrm{kg}\right.$; Neguvon ${ }^{\circledR}$ - Bayer S.A.) one week before being taken to the farm, to remove any infestation with $O$. ovis.

While indoors, the animals were fed on concentrate (Tech Ovin Unique, Socil ${ }^{\circledR}$, with $18 \%$ of crude protein) with an amount corresponding to $1 \%$ of their mean live weight and had free access to Tifton hay and tap water. Decoquinate (Deccox ${ }^{\circledR}$, Alpharma) was added to the commercial feed to prevent coccidiosis.

Every month, from April 2008 until March 2011, two tracer lambs were exposed to natural infestation with $O$. ovis larvae for 28 consecutive days, while grazing together with the same sheep flock. Immediately thereafter, the tracer lambs were euthanized. Heads were removed and cut open along their longitudinal and sagittal axis. Nasal cavity (nasal passage, septum, middle meatus and conchae) and paranasal sinuses (frontal and maxillary) were carefully examined and all larvae present were collected and counted. Larvae were preserved in $70 \%$ alcohol and identified according to their stage of development based on the descriptions by Zumpt (1965) and Capelle (1966).

\section{Sheep flock management}

The sheep farm where the tracer lambs were placed held 156 Bergamacia sheep at the beginning of the study and 202 animals at the end of the study. The sheep were kept permanently in rotational grazing on Panicum maximum cv Tanzania grass. However, due to the low amount of forage during winter and early spring (from June to October), the animals received additional corn silage feed daily.

\section{Statistical analyses}

Analysis of variance was performed in order to compare the degree of infestation throughout the year. Data were transformed using $\log _{10}(x+1)$ prior to analysis and grouped according to the season of the year, autumn (March-April-May), winter (June-July-August), spring (September-October-November) and summer (December-January-February). Significant differences between season means were determined by the Student's t-test at 5\%. Spearman's rank correlation coefficients were estimated between larval burden and climatic conditions (temperature, rainfall and air relative humidity). All analyses were performed using SAS (release 9.2).

Descriptive statistical analyses were used to summarize the data in agreement with Bush et al. (1997), using the following terms:

Prevalence: the number of hosts infested with $O$. ovis larvae divided by the number of hosts examined;

Intensity of infestation: the number of $O$. ovis larvae in a single infested host;

Mean intensity of infestation: the total number of $O$. ovis larvae found divided by the number of hosts infected with that parasite.

\section{Results}

The prevalence of $O$. ovis infestation was $50 \%$ for the tracer lambs, i.e., half of the 72 animals displayed larvae during the three years of the experiment. O. ovis larvae were present during the four seasons of the year with the highest prevalence $(61.1 \%)$ in summer and autumn (Figure 2). The highest rate of larvae recovery coincided with mean temperatures between $20^{\circ} \mathrm{C}$ and $25^{\circ} \mathrm{C}$ and air relative humidity around $70 \%$ (Figure $1 \mathrm{a}, \mathrm{b}$ ). Nevertheless, no significant correlations were observed between monthly larval

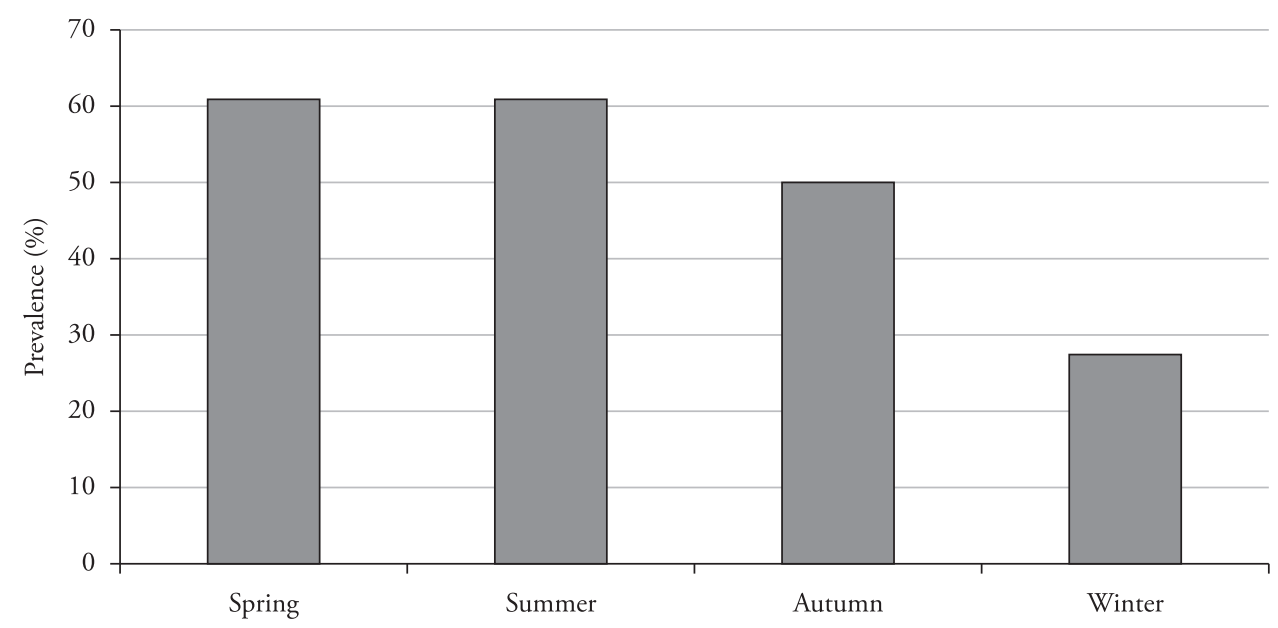

Figure 2. Seasonal prevalence of Oestrus ovis in tracer sheep from April 2008 until March 2011, Botucatu, São Paulo State. 
numbers and the climatic variables, i.e., temperature, rainfall or air relative humidity $(\mathrm{P}>0.05)$.

The mean intensity of infestation was 16.8 larvae per infested head with an average of 7.8 first larval instar (L1), 5.3 second larval instar (L2) and 3.7 third larval instar (L3) (Figure 3). The highest number of larvae recovered from a single sheep was 66, in September 2008: 64 L1 and two L2. The highest mean intensity of infestation was found at the beginning of spring in September and October 2008 (40 and 41 larvae/infested head, respectively). The mean larval burden was significantly higher in spring and summer compared to winter $(\mathrm{P}<0.05)$.

From the total 606 larvae, $46.4 \%$ was L1, while L2 and L3 represented $31.3 \%$ and $22.3 \%$ of the total larval burden, respectively. The majority of $\mathrm{L} 1$ were located in the nasal cavity (99.6\%). In contrast, L3 were found especially in the frontal sinus (97.8\%). L2 were recovered from both sites: $40 \%$ from the nasal cavity and $60 \%$ from the frontal sinus. No larvae were recovered from maxillary sinus.

Most of the tracer lambs parasitized with O. ovis (30 of 36) did not show any clinical signs of oestrosis. Only six animals presented signs, e.g., dyspnea and seromucous discharge; their larval burden was variable, ranging from 12 to 66 larvae, constituted especially of L1 and L2.

\section{Discussion}

The prevalence of $O$. ovis in tracer lambs was $50 \%$, which is less than that observed in Bagé, State of Rio Grande do Sul, Brazil, where $85.4 \%$ of sheep were infested (RIBEIRO et al., 1990). The difference between results may be explained in part by the fact that in Bagé, the animals were exposed to O. ovis infestation for a longer period of time (from one month to one year), while in the present experiment the sheep were exposed for just 28 days. Moreover, other factors may have influenced the $O$. ovis epidemiology, such as the climatic conditions of each region, size of sheep flock and management, which can result in a variable prevalence, as demonstrated by numerous studies conducted in slaughterhouses in different countries
(YILMA; DORCHIES, 1991; ABO-SHEHADA et al., 2000; SCALA et al., 2002; ALCAIDE et al., 2003; ARSLAN et al., 2009; SHOORIJEH et al., 2009).

The mean intensity of infestation reported in this study (16.8) was similar to that previously reported in Sardinia, Italy (SCALA et al., 2001) and Southwestern Spain (ALCAIDE et al., 2003), with mean intensities of 19 and 18.5 larvae per infested head, respectively; but lower than that found in Southwestern France with 24.8 larvae (YILMA; DORCHIES, 1991) and Northeastern Spain with 37.9 (GRACIA et al., 2010). It is noteworthy that a high percentage of first larval instar were found by those authors, especially during the colder months. This was not observed in the present study, where the proportion of different larval instars did not show variation throughout the experimental months.

The respective percentages of L1, L2 and L3 were 46.4\%, $31.3 \%$ and $22.3 \%$. The presence of different instars indicates that endogenous development and re-infestation with L1 occurred simultaneously. In contrast, in the Southwestern region of France, in temperate weather, L1 predominated at $90.5 \%$ of the total burden, while L2 (6.0\%) and L3 (3.5\%) displayed low proportions (YILMA; DORCHIES, 1991). A greater burden of L1 indicates the occurrence of a period of hypobiosis during the year, when O. ovis cease their development, or at least suggests a decrease in the rate of larval maturation. This was not observed in the present research, where synchronous evolution of all larval instars was observed with no evidence of hypobiosis.

Among the climatic factors influencing the oestrid fly activity, temperature, light intensity, and wind are recognized as the most important, but in the case of $O$. ovis, it has been reported that temperature is the main factor in determining fly activity (CEPEDA-PALACIOS; SCHOLL, 2000). During all years of the study, averages of maximum temperatures were between $20.8{ }^{\circ} \mathrm{C}$ and $29.8^{\circ} \mathrm{C}$. It was demonstrated that $20{ }^{\circ} \mathrm{C}$ was the minimum temperature for fly activity, while optimum temperature appears to range between 26 and $28{ }^{\circ} \mathrm{C}$ (CEPEDA-PALACIOS; SCHOLL, 2000). Therefore, the temperature conditions of the present study were optimal for fly activity during all months of the experimental years, except during winter months, especially

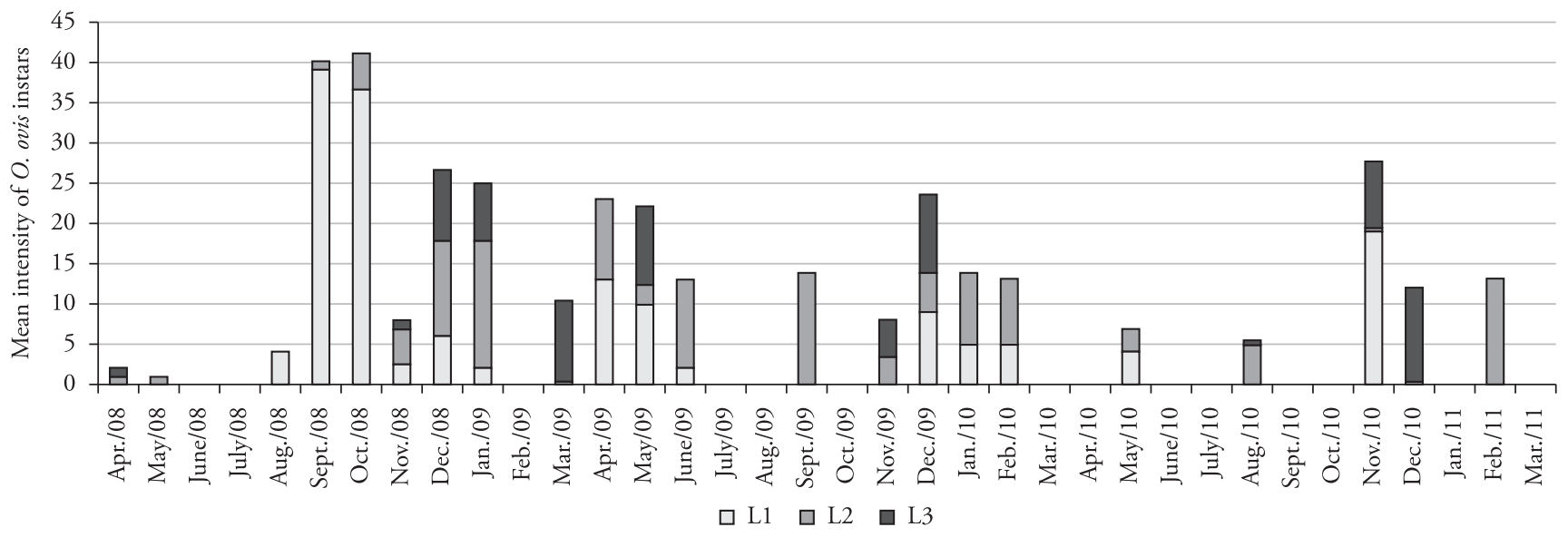

Figure 3. Monthly mean intensity of first larval instar (L1), second larval instar (L2) and third larval instar (L3) of Oestrus ovis in tracer sheep from April 2008 until March 2011, Botucatu, São Paulo State. 
in July, when regardless of a mean maximum temperature of around $25^{\circ} \mathrm{C}$, the mean of the minimum was always less than $14{ }^{\circ} \mathrm{C}$. Under these climatic conditions, the activity of flies was possibly reduced, which coincided with the lowest mean intensity of infestation in tracer sheep.

Nasal discharges and sneezing were evident in sheep at the farm during the entire study, but only six of the 72 tracer animals had clinical symptoms of oestrosis. The delay between the first infestation and the appearance of clinical signs suggests the possible involvement of a hypersensitivity phenomenon in the modulation of the infection and these first infestations are possibly not associated with clinical signs of overt oestrosis (DORCHIES et al., 1998). Due to the short period between infestation and euthanasia, most of the tracer sheep probably did not have time to develop and display any immune response through sneezing and nasal discharge, which are characteristic clinical signs of parasitism by $O$. ovis.

In conclusion, it is possible to affirm that several annual generations of adult flies may occur in the region. New studies will be necessary to evaluate the impact of oestrosis in sheep production, as well the best strategies of prophylaxis.

\section{Acknowledgements}

The authors are grateful to the technical assistance provided by Mr. Valdir A. Paniguel, Mr. Moises dos Santos and Mr. Edvaldo J. Vito. This study was funded by "Fundação de Amparo à Pesquisa do Estado de São Paulo” - FAPESP, (grant number 2008/53494-2). Bruna F. Silva (grant number 2007/58244-1) and César C. Bassetto (grant number 2009/03504-4), received financial support by FAPESP and Alessandro F.T. Amarante was supported by "Conselho Nacional de Desenvolvimento Cientifico e Tecnologico - CNPq".

\section{References}

Abo-Shehada MN, Arab B, Mekbel R, Williams D, Torgerson PR. Age and seasonal variations in the prevalence of Oestrus ovis larvae among sheep in northern Jordan. Prev Vet Med 2000; 47(3): 205-212. http:// dx.doi.org/10.1016/S0167-5877(00)00160-4

Alcaide M, Reina D, Sánchez J, Frontera E, Navarrete I. Seasonal variations in the larval burden distribution of Oestrus ovis in sheep in the southwest of Spain. Vet Parasitol 2003; 118(3-4): 235-241. PMid:14729171. http://dx.doi.org/10.1016/j.vetpar.2003.09.021

Arslan M, Kara M, Gicik Y. Epidemiology of Oestrus ovis infestations in sheep in Kars province of north-eastern Turkey. Trop Anim Health Prod 2009; 41(3): 299-305. PMid:18523857. http://dx.doi.org/10.1007/ s11250-008-9190-x

Bush AO, Lafferty KD, Lotz JM, Shostak AW. Parasitology meets ecology on its own terms: Margolis et al. revisited. J Parasitol 1997; 83(4): 575-583. PMid:9267395. http://dx.doi.org/10.2307/3284227

Capelle KJ. The occurrence of Oestrus ovis L. (Diptera: Oestridae) in the bighorn sheep from Wyoming and Montana. J Parasitol 1966; 52(3): 618-621. PMid:5942536. http://dx.doi.org/10.2307/3276337

Caracappa S, Rilli S, Zanghi P, Di Marco V, Dorchies P. Epidemiology of ovine oestrosis (Oestrus ovis Linné 1761, Diptera: Oestridae) in Sicily. Vet Parasitol 2000; 92(3): 233-237. http://dx.doi.org/10.1016/S03044017(00)00317-4
Cepeda-Palacios R, Scholl PJ. Factors affecting the larvipositional activity of Oestrus ovis gravid females (Diptera: Oestridae). Vet Parasitol 2000; 91(1-2): 93-105. http://dx.doi.org/10.1016/S0304-4017(00)00265-X

Cobbett NG, Mitchell WC. Further observations on the life cycle and incidence of the sheep bot, Oestrus ovis, in New Mexico and Texas. Am $J$ Vet Res 1941; 2: 358-366.

Dorchies P, Duranton C, Jacquiet P. Pathophysiology of Oestrus ovis infection in sheep and goats: a review. Vet Rec 1998; 142(18): 487-489. PMid:9612915. http://dx.doi.org/10.1136/vr.142.18.487

Dorchies P, Wahetra S, Lepetitcolin E, Prevot F, Grisez C, Bergeaud JP, et al. The relationship between nasal myiasis and the prevalence of enzootic nasal tumours and the effects of treatment of Oestrus ovis and milk production in dairy ewes of Roquefort cheese area. Vet Parasitol 2003; 113(2): 169-174. http://dx.doi.org/10.1016/S03044017(03)00032-3

Gracia MJ, Lucientes J, Peribáñez MA, Castillo JA, Calvete C, Ferrer LM. Epidemiology of Oestrus ovis infection of sheep in northeast Spain (mid-Ebro Valley). Trop Anim Health Prod 2010; 42(5): 811-813. PMid:19937114. http://dx.doi.org/10.1007/s11250-009-9503-8

Hall M, Wall R. Myiasis of Humans and Domestic Animals. Adv Parasitol 1995; 35: 257-334. http://dx.doi.org/10.1016/S0065-308X(08)60073-1

Horak IG, Snijders AJ. The effect of Oestrus ovis infestation on merino lambs. Vet Rec 1974; 94(1): 12-16. PMid:4817058. http://dx.doi. org/10.1136/vr.94.1.12

Oliveira CMB, Oliveira LO, Torres JR. Oestrus ovis larvae distribution in the head of naturally infested sheep. Arq Fac Vet UFRGS 1999; 27(2): 87-92.

Ramos CI, Bellato V, Souza AP, Avila VS, Coutinho GC, Dalagnol CA. Epidemiologia de Oestrus ovis (Diptera: Oestridae) em ovinos no Planalto Catarinense. Cienc Rural 2006; 36(1): 173-178. http://dx.doi. org/10.1590/S0103-84782006000100026

Ribeiro VLS, Oliveira CMB, Branco FPJA. Prevalência e variaçôes mensais das larvas de Oestrus ovis (Linneus, 1761) em ovinos no município de Bagé, RS, Brasil. Arq Bras Med Vet Zootec 1990; 42(3): 211-221.

Scala A, Paz-Silva A, Suárez JL, López C, Díaz P, Díez-Baños P, et al. Chronobiology of Oestrus ovis (Diptera: Oestridae) in Sardinia, Italy: guidelines to chemoprophylaxis. J Med Entomol 2002; 39(4): 652-657. PMid:12144298. http://dx.doi.org/10.1603/0022-2585-39.4.652

Scala A, Solinas G, Citterio CV, Kramer LH, Genchi C. Sheep oestrosis (Oestrus ovis Linné 1761, Diptera: Oestridae) in Sardinia, Italy. Vet Parasitol 2001; 102(1-2): 133-141. http://dx.doi.org/10.1016/S03044017(01)00515-5

Shoorijeh S, Negahban S, Tamadon A, Behzadi M. Prevalence and intensity of Oestrus ovis in sheep of Shiraz, southern Iran. Trop Anim Health Prod 2009; 41(7): 1259-1262. PMid:19184506. http://dx.doi. org/10.1007/s11250-009-9309-8

Yilma JM, Dorchies P. Epidemiology of Oestrus ovis in southwest France. Vet Parasitol 1991; 40(3-4): 315-323. http://dx.doi.org/10.1016/03044017(91)90111-8

Zumpt P. Myiasis in man and animals in the Old World. London: Butterworths; 1965. PMid:14272962. 